DOI:10.17951/h.2015.49.4.291

\begin{tabular}{lcl}
\hline \multicolumn{3}{c}{ A N N A L E S } \\
UNIVERSITATIS MARIAE CURIE-SKŁODOWSKA \\
LUBLIN - POLONIA \\
VOL. XLIX, 4 & SECTIO H \\
\hline
\end{tabular}

Uniwersytet Marii Curie-Skłodowskiej w Lublinie, Wydział Ekonomiczny

\title{
KATARZYNA KRÓLIK-KOŁTUNIK
}

katarzyna.krolik-koltunik@umcs.pl

\section{Przymusowy wykup akcji na Giełdzie Papierów Wartościowych $w$ Warszawie}

Squeeze-Out on the Warsaw Stock Exchange

Słowa kluczowe: akcje, przymusowy wykup, rynek kapitałowy

Keywords: stock, squeeze-out, capital market

Kod JEL: G190, G290, G340

\section{Wstęp}

Jedną z głównych instytucji rynku kapitałowego jest giełda papierów wartościowych. Giełdę określa się mianem rynku regulowanego, czyli działającego na podstawie odpowiednich unormowań prawnych (ustaw, rozporządzeń, regulaminów itp.). Przepisy regulujące funkcjonowanie rynku kapitałowego mają na celu przede wszystkim ochronę podmiotów cechujących się słabszą pozycją, np. nieprofesjonalnych uczestników obrotu, inwestorów indywidualnych czy mniejszościowych akcjonariuszy. Można jednak znaleźć takie przepisy w prawie, które dbają o interesy większościowych akcjonariuszy. Przykładem są przepisy o przymusowym wykupie akcji, nazywanym potocznie squeeze-out.

Celem niniejszego opracowania jest omówienie przymusowego wykupu akcji w odniesieniu do spółek publicznych oraz zbadanie występowania tego zjawiska na Giełdzie Papierów Wartościowych w Warszawie. 


\section{Przymusowy wykup akcji (squeeze-out) i przymusowy odkup akcji (sell-out right)}

W przepisach prawnych istnieją dwa rodzaje przymusowych wykupów bądź odkupów akcji. Pierwsza możliwość to przymusowy wykup akcji od akcjonariuszy mniejszościowych. Polega on na tym, że akcjonariusz większościowy po osiągnięciu określonego udziału w kapitale zakładowym lub ogólnej liczbie głosów może żądać, aby akcjonariusze mniejszościowi sprzedali mu swoje akcje. Tę procedurę zwykle określa się mianem przymusowego wykupu akcji lub stosuje się angielskie określenie squeeze-out, thumaczone jako „wyciskanie” akcjonariuszy mniejszościowych. Druga możliwość to przymusowy odkup akcji, który polega na tym, że to akcjonariusze mniejszościowi mają prawo żądać, aby akcjonariusz większościowy odkupił od nich akcje. Ta procedura jest określana również jako prawo przymusowego wykupu lub stosuje się angielskie określenia: reverse squeeze-out, buy-out right lub sell-out right ${ }^{1}$.

Większościowi akcjonariusze decydują się na przymusowy wykup akcji, mając na celu uwolnienie się od kosztów wynikających z funkcjonowania w spółce drobnych akcjonariuszy [Rusek, Hajdecki, 2008, s. 75]. Wykupienie udziałów od akcjonariuszy mniejszościowych wpływa na przyspieszenie procesów decyzyjnych i usprawnienie zarządzania spółką. Możliwe jest podejmowanie strategicznych decyzji charakteryzujących się podwyższonym ryzykiem, które mogłyby spowodować sprzeciw ze strony mniejszościowych akcjonariuszy. Dzięki przymusowemu wykupowi akcji spółka chroni się przed zachowaniami tzw. drobnego akcjonariatu określanymi jako „szantaż korporacyjny”, czyli sytuacjami, kiedy prawa mniejszości są nadużywane, np. drobni akcjonariusze konsekwentnie zaskarżają uchwały w celu utrudniania zarządzania spółką. Spółce, w której nie występują drobni akcjonariusze, łatwiej jest też pozyskać inwestora strategicznego [Pinior, Wyrzykowski, 2009, s. 9]. W przypadku spółek publicznych przeprowadzenie przymusowego wykupu akcji jest najczęściej jednym z etapów w procesie wycofywania spółki z obrotu giełdowego i zniesienia dematerializacji akcji.

Celem wprowadzenia do przepisów prawnych instytucji przymusowego odkupu akcji była ochrona interesów akcjonariuszy mniejszościowych, chodziło o umożliwienie im „wyjścia” ze spółki w sytuacji, gdy pojawia się dominujący akcjonariusz, a także zapewnienie im odpowiedniej ceny w zamian za odkupywane akcje w warunkach, gdy ich pozycja stała się w zasadzie marginalna.

\section{Przepisy regulujące przymusowy wykup akcji}

Przymusowy wykup akcji jest rozwiązaniem stosunkowo nowym w polskim prawie. Pojawiło się ono po raz pierwszy w ustawie z dnia 15 września 2000 r. - Kodeks spółek handlowych (dalej: KSH) (Dz. U. 2000, nr 94, poz. 1037 z późn. zm.).

1 Dokładne porównanie przymusowego wykupu i odkupu akcji w spółkach niepublicznych można znaleźć w publikacji D. Nowaka [2006, s. 25-27]. 
W art. 418 znajdują się przepisy normujące przymusowy wykup akcji, zaś art. $418^{1}$ odnosi się do przymusowego odkupu akcji. Wcześniejsze uregulowania Kodeksu handlowego z 1934 r. nie zawierały stosownych przepisów.

Omawiane zagadnienie zostało również uregulowane w prawie Unii Europejskiej, w dyrektywie z 21 kwietnia 2004 r. 2004/25/WE Parlamentu Europejskiego i Rady o publicznych ofertach przejęcia (Dz. U. UE. L 2004, nr 142, poz. 12). Art. 15 dyrektywy reguluje przymusowy wykup akcji (określony „,prawem przymusowej sprzedaży"), zaś art. 16 odnosi się do przymusowego odkupu akcji (określonego w dyrektywie ,prawem przymusowego wykupu”). Wskutek implementacji tej dyrektywy zostały zmienione przepisy zawarte w KSH, a także wprowadzono uregulowania przymusowego wykupu akcji w spółkach publicznych, jako że wspomniane art. 418 i $418^{1} \mathrm{KSH}$ odnoszą się do spółek niepublicznych, czyli niedopuszczonych do obrotu giełdowego.

Przepisy odnoszące się do spółek publicznych znalazły się w ustawie z dnia 29 lipca 2005 r. o ofercie publicznej i warunkach wprowadzania instrumentów finansowych do zorganizowanego systemu obrotu oraz o spółkach publicznych (dalej: ustawa o ofercie publicznej) (Dz. U. 2005, nr 184, poz. 1539 z poźn. zm.). Poprzednia ustawa z 1997 r. - Prawo o publicznym obrocie papierami wartościowymi nie regulowała tej kwestii. Przymusowy wykup akcji w spółkach publicznych (którego dotyczy niniejsze opracowanie) jest unormowany w art. 82 ustawy o ofercie publicznej, zaś art. 83 odnosi się do przymusowego odkupu akcji. Szczegółowe uregulowania przymusowego wykupu akcji w spółkach publicznych zawarte są również w Rozporządzeniu Ministra Finansów z dnia 14 listopada 2005 r. w sprawie nabywania akcji spółki publicznej w drodze przymusowego wykupu (Dz. U. 2005, $\mathrm{nr} 229$, poz. 1948). Dotyczą one sposobu ogłaszania informacji o zamiarze nabycia akcji spółki publicznej w drodze przymusowego wykupu oraz warunków nabywania akcji objętych przymusowym wykupem.

\section{Przymusowy wykup akcji w spótkach publicznych - zasady dzialania}

Zgodnie z obowiązującymi przepisami przymusowego wykupu akcji spółki publicznej może dokonać akcjonariusz, który osiągnął lub przekroczył 90\% ogólnej liczby głosów w spółce ${ }^{2}$. Prawo to przysługuje również akcjonariuszowi, jeśli wspomniany próg $90 \%$ osiągnął lub przekroczył wspólnie z podmiotami zależnymi lub dominującymi względem niego. Możliwe jest też zawarcie porozumienia (ustnego lub pisemnego) z innymi akcjonariuszami w sprawie m.in. przymusowego wykupu akcji. Akcjonariusze ci muszą wspólnie osiągnąć lub przekroczyć 90\% ogólnej liczby

2 Unormowania KSH określają tę granicę na poziomie 95\% udziałów w kapitale zakładowym. W odniesieniu do spółek publicznych wymagany próg jest więc niższy i odnosi się go do ogólnej liczby głosów, a nie do kapitału zakładowego. 
głosów w spółce. Przymusowy wykup jest przeprowadzany bez zgody akcjonariuszy, których akcje są wykupywane.

Procedura wykupu jest przeprowadzana za pośrednictwem podmiotu, który prowadzi działalność maklerską na terytorium Polski. Podmiot ten ma obowiązek, nie później niż na 14 dni roboczych przed rozpoczęciem przymusowego wykupu, zawiadomić o zamiarze jego ogłoszenia równocześnie Komisję Nadzoru Finansowego i spółkę prowadzącą rynek regulowany, na którym są notowane akcje objęte przymusowym wykupem ${ }^{3}$. Ogłoszenie żądania sprzedaży akcji w ramach przymusowego wykupu musi być poprzedzone ustanowieniem zabezpieczenia w wysokości co najmniej $100 \%$ wartości akcji, które mają być wykupione. Ustanowienie tego zabezpieczenia musi być udokumentowane zaświadczeniem od banku lub innej instytucji finansowej udzielającej zabezpieczenia lub pośredniczącej w jego udzieleniu. Nie dopuszcza się możliwości odstąpienia od ogłoszonego przymusowego wykupu.

Ogłoszenie zamiaru nabycia akcji w drodze przymusowego wykupu odbywa się przez przekazanie treści ogłoszenia do co najmniej jednej agencji informacyjnej, a także do co najmniej jednego dziennika o zasięgu ogólnopolskim, następnie podmioty te upubliczniają tę wiadomość. W treści ogłoszenia zostają zawarte m.in. następujące informacje:

- treść żądania oraz wskazanie jego podstawy prawnej,

- dane (imienne i adresowe) żądającego sprzedaży, podmiotu wykupującego oraz podmiotu pośredniczącego $\mathrm{w}$ wykupie,

- oznaczenie akcji objętych przymusowym wykupem oraz liczbę i rodzaj tych akcji wraz ze wskazaniem liczby głosów na walnym zgromadzeniu, do jakiej uprawnia jedna akcja danego rodzaju, a także wysokość kapitału zakładowego i łączną liczbę akcji spółki,

- procentową liczbę głosów z akcji objętych przymusowym wykupem i odpowiadającą jej liczbę akcji,

- proporcje, w jakich nastąpi nabycie akcji przez każdy z podmiotów uczestniczących w wykupie,

- cenę wykupu,

- procentową liczbę głosów z akcji i odpowiadającą jej liczbę akcji, jaką samodzielnie posiada żądający sprzedaży,

- wskazanie podmiotów zależnych od żądającego sprzedaży lub wobec niego dominujących oraz podmiotów będących stronami zawartego z nim porozumienia, a także jaką procentową liczbę głosów z akcji i odpowiadającą jej liczbę akcji posiada każdy z tych podmiotów,

- dzień rozpoczęcia przymusowego wykupu,

3 Jeśli akcje są notowane na kilku rynkach regulowanych, to zawiadomienie musi być skierowane do wszystkich spółek prowadzących te rynki. 
- dzień wykupu,

- miejsce i termin wydawania akcji objętych przymusowym wykupem,

- miejsce, termin i sposób zapłaty za nabywane akcje.

Po podaniu wyżej wymienionej treści do wiadomości publicznej, podmiot pośredniczący w wykupie przekazuje odpowiednie informacje do Krajowego Depozytu Papierów Wartościowych oraz do spółki będącej emitentem akcji objętych przymusowym wykupem.

Procedura samego wykupu różni się dla akcji zdematerializowanych i akcji posiadających formę dokumentu. W przypadku akcji zdematerializowanych podmioty prowadzące rachunki papierów wartościowych, na których są zapisane akcje objęte przymusowym wykupem, po otrzymaniu informacji od KDPW dokonują blokady tych akcji na rachunkach od dnia otrzymania informacji do dnia wykupu. W dniu wykupu KDPW przenosi akcje objęte przymusowym wykupem na konto depozytowe podmiotu pośredniczącego $\mathrm{w}$ wykupie, a następnie zostają one zapisane na rachunku papierów wartościowych podmiotu dokonującego wykupu w zamian za zapłatę ceny wykupu.

W przypadku akcji posiadających formę dokumentu wykup następuje w wyniku przekazania dokumentów akcji w wyznaczonym miejscu i czasie w zamian za zapłatę ceny. Gdyby ta wymiana nie doszła do skutku, to na specjalnym rachunku pieniężnym zostają zdeponowane przez wykupującego środki przeznaczone na zapłatę za te akcje. Następnie po upływie terminu wskazanego w ogłoszeniu wykupujący występuje do zarządu spółki o unieważnienie niewydanych dokumentów akcji. Zarząd spółki unieważnia te akcje, a w zamian za nie wydaje podmiotowi wykupującemu nowe dokumenty akcji tej samej serii i o tym samym numerze.

Cena, po jakiej jest dokonywany przymusowy wykup akcji, jest ustalana zgodnie z art. 79 ust. 1-3 ustawy o ofercie publicznej. Musi być ona jednolita dla wszystkich akcji. W przypadku spółek notowanych na rynku regulowanym ustalona cena nie może być niższa niż średnia cena rynkowa $\mathrm{z}$ okresu 6 miesięcy poprzedzających wezwanie lub krótszego okresu, jeśli spółka była notowana krócej niż pół roku. W sytuacjach, gdy niemożliwe byłoby ustalenie ceny w ten sposób lub w przypadku spółek, wobec których toczy się postępowanie układowe lub upadłościowe, ustalona cena nie może być niższa od wartości godziwej.

Ponadto cena akcji zaproponowana w wezwaniu o przymusowym wykupie nie może być niższa od najwyższej ceny, jaką podmiot wzywający do sprzedaży zapłacił za te akcje w ciągu ostatnich 12 miesięcy przed wezwaniem oraz nie niższa od najwyższej wartości rzeczy lub praw, które podmiot wydał w zamian za akcje będące przedmiotem wezwania w okresie ostatnich 12 miesięcy. Proponowana cena nie może być również niższa od średniej ceny rynkowej z okresu 3 miesięcy obrotu na rynku regulowanym poprzedzających wezwanie. Dodatkowo, jeśli osiągnięcie lub przekroczenie progu 90\% ogólnej liczby głosów nastąpiło w drodze wezwania na sprzedaż wszystkich pozostałych akcji, to cena wykupu nie może być niższa od ceny proponowanej w tym wezwaniu. 


\section{Zjawisko squeeze-outu na Giełdzie Papierów Wartościowych w Warszawie}

Celem badania było określenie występowania zjawiska przymusowego wykupu akcji (tzw. squeeze-outu) na Giełdzie Papierów Wartościowych w Warszawie. Przepisy prawne odnoszące się do tej kwestii zostały wprowadzone w 2005 r. ustawą o ofercie publicznej. Okres badawczy obejmował więc czas od momentu wejścia w życie ustawy do najbardziej aktualnych danych, czyli do końca czerwca 2015 r. Tab. 1 zawiera ilościowe zestawienie przymusowych wykupów akcji przeprowadzonych w spółkach notowanych na GPW w Warszawie w latach 2005-2015. Szczegółowe informacje dotyczące ogłoszonych przymusowych wykupów są zawarte w tab. 2.

Tab. 1. Liczba przymusowych wykupów akcji ogłoszonych w latach 2005-2015

\begin{tabular}{|l|c|}
\hline \multicolumn{1}{|c|}{ Rok } & $\begin{array}{c}\text { Liczba ogloszonych przymusowych } \\
\text { wykupów akcji }\end{array}$ \\
\hline 2005 & 0 \\
\hline 2006 & 7 \\
\hline 2007 & 5 \\
\hline 2008 & 3 \\
\hline 2009 & 2 \\
\hline 2010 & 10 \\
\hline 2011 & 1 \\
\hline 2012 & 5 \\
\hline 2013 & 2 \\
\hline 2014 & 6 \\
\hline $2015(\mathrm{I}-\mathrm{IV})$ & 1 \\
\hline
\end{tabular}

Źródło: opracowanie własne na podstawie danych: [www.gpwinfostrefa.pl].

Tab. 2. Przymusowe wykupy akcji ogłoszone w latach 2006-2015

\begin{tabular}{|l|l|c|c|}
\hline \multicolumn{1}{|c|}{ Spólka } & \multicolumn{1}{|c|}{$\begin{array}{c}\text { Podmiot oglaszający wezwanie } \\
\text { (glówny akcjonariusz) }\end{array}$} & $\begin{array}{c}\text { Procentowy } \\
\text { udzial glównego } \\
\text { akcjonariusza }\end{array}$ & $\begin{array}{c}\text { Data wezwania } \\
\text { squeeze-out }\end{array}$ \\
\hline ORFE & OPG Groep & 91,53 & 13.01 .2006 \\
\hline TUiR Warta & KBC Verzekeringen & 99,74 & 28.02 .2006 \\
\hline SOKOŁÓW & Saturn Nordic Holding & 91,75 & 12.06 .2006 \\
\hline FBT Milmet & VTK Cylinders & 96,42 & 21.07 .2006 \\
\hline Jelfa & Sanitas Polska & 95,25 & 24.07 .2006 \\
\hline Grupa Onet & TVN & 97,69 & 16.10 .2006 \\
\hline Ekodrob & Animex & 94,92 & 14.09 .2006 \\
\hline POLMOS Lublin & Shot Acquisitions & 96,05 & 15.02 .2007 \\
\hline BROKER FM & Bauer Media Invest & 90,59 & 16.03 .2007 \\
\hline UNIMIL & Ansell Healthcare Europe & 90,59 & 19.04 .2007 \\
\hline Polmos Białystok & Carey Agri & 91,00 & 14.06 .2007 \\
\hline Provimi-Rolimpex & Provimi Holding & 97,59 & 27.06 .2007 \\
\hline Interia & Bauer Media Invest & 99,00 & 11.02 .2008 \\
\hline PRATERM & Dalkia & 99,04 & 15.05 .2008 \\
\hline Gadu Gadu & MIH Poland & 97,51 & 23.06 .2008 \\
\hline
\end{tabular}


Pobrane z czasopisma Annales H - Oeconomia http://oeconomia.annales.umcs.pl Data: 26/04/2023 15:03:28

PRZYMUSOWY WYKUP AKCJI NA GIEŁDZIE PAPIERÓW WARTOŚCIOWYCH W WARSZAWIE

\begin{tabular}{|c|c|c|c|}
\hline Artman & LPP & 99,75 & 26.01 .2009 \\
\hline SPRAY & Vectra Inwestycje & 98,97 & 01.06 .2009 \\
\hline Bankier.pl & MIH Allegro & 91,16 & 29.01 .2010 \\
\hline HTL-Strefa & Terantium Investment & 97,68 & 22.02 .2010 \\
\hline Optopol Technology & Canon Inc. oraz Adam Bogdani & 99,35 & 23.03 .2010 \\
\hline WSIP & Pahoa Investments & 90,42 & 30.04 .2010 \\
\hline Teta & Unit4 & 93,01 & 30.07 .2010 \\
\hline Kable & NKT Cables & 90,61 & 30.08 .2010 \\
\hline Nepentes & Sanofi-Aventis & 99,70 & 13.09 .2010 \\
\hline DZ Bank Polska & DZ Bank & 99,87 & 23.09 .2010 \\
\hline WOLA INFO & Devoteam & 93,23 & 08.10 .2010 \\
\hline Ruch & Lurena & 90,03 & 20.10 .2010 \\
\hline Multimedia Polska & Lubotech Limited i inni & 90,57 & 23.08 .2011 \\
\hline Elstar Oil & Archer Daniels Miland & 97,74 & 07.12 .2012 \\
\hline Mondi Świecie & Mondi International i Framondi & 93,19 & 14.05 .2012 \\
\hline TU Europa & Talanx International, Meij Yasuda, Getin Holding & 94,52 & 19.07.2012 \\
\hline Centrum Klima & LINDAB & 97,30 & 01.08 .2012 \\
\hline POLLENA-EWA & TZMO & 93,56 & 08.11 .2012 \\
\hline Zelmer & $\mathrm{BSH}$ & 97,78 & 12.04 .2013 \\
\hline POL-AQUA & DRAGADOS & 96,18 & 18.10 .2013 \\
\hline Barlinek & Michał Sołowow & 94,34 & 08.01 .2014 \\
\hline Armatura Kraków & PZU FIZ Aktywów Niepublicznych BIS 2 & 92,75 & 16.01 .2014 \\
\hline Nordea Bank & PKO BP & 99,82 & 06.05 .2014 \\
\hline Bakalland & Innova Phoenix i inni & 91,10 & 12.11 .2014 \\
\hline ZPC Mieszko & Bisantio Investments & 91,01 & 26.11 .2014 \\
\hline BGŻ & BNP Paribas i Rabobank & 98,98 & 23.12 .2014 \\
\hline Bipromet & KGHM & 91,23 & 22.04 .2015 \\
\hline
\end{tabular}

Źródło: opracowanie własne na podstawie danych: [www.gpwinfostrefa.pl].

W badanym okresie przymusowy wykup akcji spółek notowanych na GPW w Warszawie został przeprowadzony 42 razy. Rekordowy pod tym względem był 2010 r., kiedy ogłoszono 10 squeeze-outów. Średnio w jednym roku przeprowadzano ok. 4-5 przymusowych wykupów. Analizując częstotliwość występowania wezwań przymusowych wykupów akcji na tle koniunktury giełdowej (rys. 1), można zaobserwować, że w okresie hossy do mniej więcej połowy 2007 r. squeeze-outów było stosunkowo dużo (12 w ciągu półtora roku). Przez kolejne dwa i pół roku (był to okres gwałtownych spadków na giełdzie) ogłoszono tylko pięć przymusowych wykupów akcji. Później przyszedł 2010 r. z 10 wezwaniami i kolejny, 2011 r., w którym był tylko jeden przymusowy wykup. W następnych latach sytuacja nieco się unormowała. W latach 2012-2014 squeeze-out był przeprowadzany średnio w 4-5 spółkach rocznie.

Dalsze losy spółek, w których przeprowadzono przymusowy wykup akcji, są podobne do siebie. W 41 przypadkach spółki zostały wycofane z obrotu giełdowego i zniknęły z tego rynku. Jedynym wyjątkiem jest bank BGŻ, który po fuzji z bankiem BNP Paribas (również notowanym na GPW) jest dalej notowany na giełdzie, lecz już pod nową, wspólną nazwą BGŻ BNP Paribas S.A. 


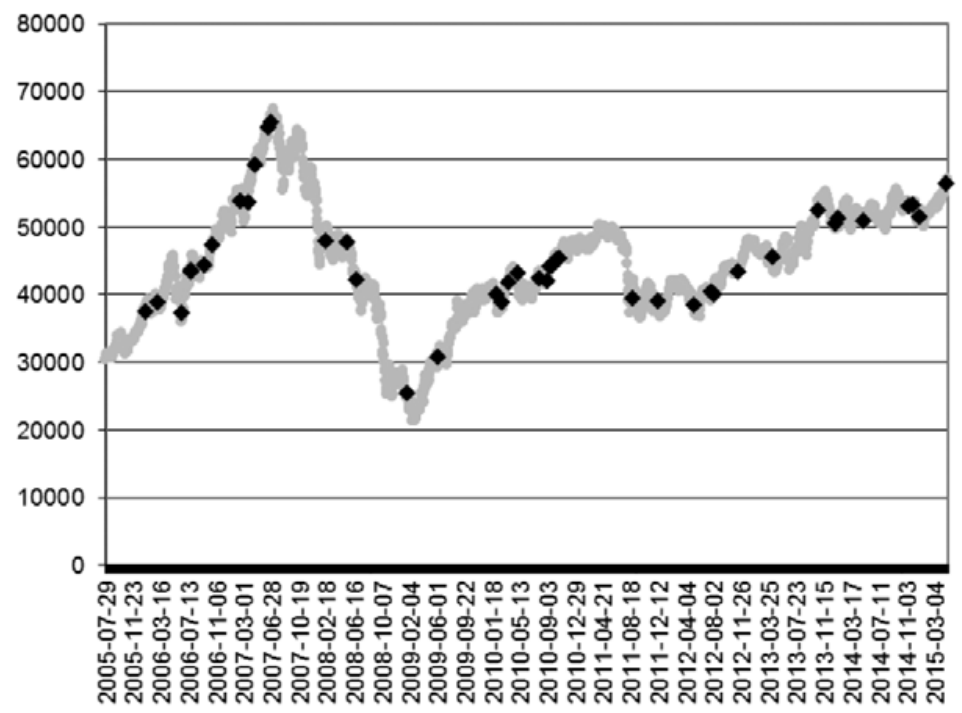

$\longrightarrow$ Wartość indeksu WIG (w pkt.) $\rightarrow$ Data wezwań squeeze-out

Rys. 1. Przymusowe wykupy akcji na tle indeksu WIG

Źródło: opracowanie własne na podstawie danych: [www.gpwinfostrefa.pl].

\section{Zakończenie}

Przepisy dotyczące przymusowego wykupu akcji są raczej nietypowym przykładem przepisów regulujących funkcjonowanie rynku kapitałowego. Większość z nich ma na celu ochronę nieprofesjonalnych uczestników obrotu giełdowego. Przepisy dotyczące squeeze-outu mają zaś chronić większościowych udziałowców spółki.

W latach 2005-2015 (do czerwca) przeprowadzono 42 przymusowe wykupy akcji spółek notowanych na Giełdzie Papierów Wartościowych w Warszawie. W analizowanym okresie można zaobserwować nieregularną częstotliwość występowania tego zjawiska, co mogło być związane z ogólną koniunkturą na giełdzie.

Spółki, w których przeprowadzono przymusowy wykup akcji, w większości przypadków zostały przyjęte przez większościowego udziałowca (np. inwestora strategicznego) i wycofane z obrotu giełdowego. Squeeze-out jest najczęściej jednym z kroków w tej procedurze i poprzedza zniesienie dematerializacji akcji, czyli przywrócenie im formy papierowego dokumentu. Decyzja o zniesieniu dematerializacji należy do kompetencji walnego zgromadzenia akcjonariuszy i wymaga uchwały podjętej większością $4 / 5$ głosów. Aby przeprowadzić squeeze-out, trzeba zgromadzić co najmniej 90\% ogólnej liczby głosów w spółce. Możliwe jest więc wycofanie spółki z giełdy bez przeprowadzania przymusowego wykupu. Jednak większość spółek w takiej sytuacji decydowało się na squeeze-out w celu przejęcia całkowitej 
kontroli nad spółką i „pozbycia” się ze spółki mniejszościowych akcjonariuszy, którzy w pewnych sytuacjach mogą się okazać kłopotliwi.

\section{Bibliografia}

Dyrektywa z 21 kwietnia 2004 r. 2004/25/WE Parlamentu Europejskiego i Rady o publicznych ofertach przejęcia (Dz. U. UE. L 2004, nr 142, poz. 12).

Nowak D., Squeeze-out a sell out right-porównanie, „Edukacja Prawnicza” 2006, nr 6(81).

Pinior P., Wyrzykowski W., Przymusowy wykup $i$ odkup akcji $w$ spółkach publicznych i niepublicznych, „Prawo Spółek” 2008, nr 9.

Rusek J., Hajdecki P., Squeeze out, czyli wyciskanie akcjonariusza mniejszościowego, „Nasz Rynek Kapitałowy" 2008, nr 5.

Rozporządzenie Ministra Finansów z dnia 14 listopada 2005 r. w sprawie nabywania akcji spółki publicznej w drodze przymusowego wykupu (Dz. U. 2005, nr 229, poz. 1948).

Ustawa z dnia 15 września 2000 r. - Kodeks spółek handlowych (Dz. U. 2000, nr 94, poz. 1037 z późn. zm.). Ustawa z dnia 29 lipca 2005 r. o ofercie publicznej i warunkach wprowadzania instrumentów finansowych do zorganizowanego systemu obrotu oraz o spółkach publicznych (Dz. U. 2005, nr 184, poz. 1539 z poźn. zm.).

www.gpwinfostrefa.pl [data dostępu: 10.05.2015].

\section{Squeeze-Out on the Warsaw Stock Exchange}

The provisions concerning the squeeze-out are rather an untypical example of regulations governing functioning of the capital market. The majority of them is aimed at protecting non-professional trading participants, whereas the provisions concerning the squeeze-out are supposed to protect majority shareholders. The aim of this paper is to discuss the squeeze-out in public companies and to examine appearing of this phenomenon on the Warsaw Stock Exchange.

\section{Przymusowy wykup akcji na Giełdzie Papierów Wartościowych w Warszawie}

Przepisy dotyczące przymusowego wykupu akcji są raczej nietypowym przykładem przepisów regulujących funkcjonowanie rynku kapitałowego. Większość z nich ma na celu ochronę nieprofesjonalnych uczestników obrotu giełdowego, podczas gdy przepisy dotyczące squeeze-outu mają chronić większościowych udziałowców spółki. Celem opracowania jest omówienie przymusowego wykupu akcji w odniesieniu do spółek publicznych oraz zbadanie występowania tego zjawiska na Giełdzie Papierów Wartościowych w Warszawie. 